\title{
Structural changes in the digestive glands of larval Antarctic krill (Euphausia superba) during starvation
}

\author{
Toshihiro Yoshida $\cdot$ So Kawaguchi $\cdot$ Bettina Meyer · \\ Patti Virtue · Jennifer Penschow $\cdot$ Gerry Nash
}

Received: 23 June 2008 / Revised: 1 December 2008 / Accepted: 1 December 2008 / Published online: 14 January 2009

(C) Springer-Verlag 2008

\begin{abstract}
The effects of starvation on ultrastructure of digestive gland cells were studied in furcilia larvae of Antarctic krill (Euphausia superba: hereafter krill). Under laboratory conditions, larvae were starved for $0,5,10,15,20$ and 25 days, and their R-cells were investigated by transmission electron microscope. R-cells are thought to play a role in the storage and absorption of nutrients. In fed larvae, numerous mitochondria scattered homogenously, and densely packed microvilli were observed on the apical surface of R-cells. After 5 days of starvation, mitochondria were swollen and were found concentrated in the apical region in R-cells. A decrease in cell volume and an increase in thickness of the basal lamina with many irregular infoldings were observed after 10-15 days of starvation. Lipid droplets were rarely found in the R-cells regardless of whether larvae had been fed or starved suggesting an inability to store lipid. Without the ability to store energy in the form of lipid, survival would be dependant on sourcing continuous food until maturation.
\end{abstract}

T. Yoshida $(\bowtie) \cdot$ P. Virtue

Institute of Antarctic and Southern Ocean Studies,

University of Tasmania, Private Bag 77, Hobart,

TAS 7001, Australia

e-mail: toshi.yoshida@aad.gov.au

T. Yoshida $\cdot$ S. Kawaguchi $\cdot$ J. Penschow $\cdot$ G. Nash

Australian Government Antarctic Division,

Channel Highway, Kingston, TAS 7050, Australia

B. Meyer

Scientific Division Biological Oceanography,

Alfred Wegener Institute for Polar and Marine Research,

Handelshafen 12, 27570 Bremerhaven, Germany

T. Yoshida

ACE/CRC (Antarctic Climate and Ecosystem,

Cooperate Research Centre), Hobart, Australia

\section{Introduction}

Antarctic krill (Euphausia superba: hereafter krill) plays a key role in the Southern Ocean ecosystems, being the major food item for most of Antarctic carnivores, such as whales, seals, penguins and sea birds. Studies on krill larval ecology are limited (e.g. Ross and Quetin 1989; Daly 1990; Meyer et al. 2002; Meyer and Oettle 2005) but important since the survival rates during the early life stages ultimately determines the population size of krill. Eggs hatch and develop through several embryonic stages to larval krill during summer. They continue to develop through the winter into juvenile krill by the subsequent spring. Recruitment success depends on both condition of the larvae approaching winter (reflecting reproductive output, larval growth and survivorship during summer/autumn) and on larval growth and survival during their first winter.

In contrast to adults, krill larvae have low lipid reserves and are therefore unable to tolerate long starvation periods (Hagen 1988; Hagen et al. 2001). Moreover, they are unable to meet their metabolic demands from the autotrophic material available in the water column, making them dependent on the biota associated within and below the sea ice for survival and development (e.g. Daly 1990; Ross and Quetin 1991; Meyer et al. 2002). Quetin and Ross (2003) reported that there were two critical larval periods in the first year of a krill's life. The first feeding stage Calyptopis I (CI) is critical as the larvae have to find adequate food within 10-14 days. The second critical period is the first winter when phytoplankton in water column are scarce (Smith et al. 1996).

Laboratory studies investigating starvation in krill larvae have described strategies used to survive these critical periods. The most characteristic effects of starvation have been observed in ultrastructural changes in the digestive system, 
particularly in the R (resorptive)-cells. Vogt et al. (1985) reported substantial changes in the R-cells in the digestive glands of the decapod Penaeus monodon subjected to different diets. They concluded that R-cells can be used to monitor the nutritional value of diets in decapods. Further, in the decapod Hyas araneus, Storch and Anger (1983) found that the reestablishment of the ultrastructure of Rcells is not possible after a certain period of food deprivation. This period was coined point of no return (PNR) which is the time after which an animal loses its capability to recover from nutritional stress. After passing the PNR, starved, and subsequently fed animals, are unable to recover from the effects of prolonged starvation. To date there are no studies investigating the ultrastructure of the digestive gland of krill with regard to nutritional stress.

The aim of this study was to examine the ultrastructural changes in R-cells of larval krill through starvation. We used furcilia IV (FIV) and furcilia V (FV) larvae because these are the most critical life stages of krill, which occur in early winter. Any delays in the timing of sea ice formation at this time will mean the larvae will have limited food and must be able to survive short-term starvation periods. The result from this study provides further insight into adaptations of furcilia larvae to environmental conditions during winter.

\section{Materials and methods}

Adult krill were collected during the marine research cruise 'BROKE-West', which was carried out from 2nd of January to 11th of March 2006 in the western Indian Ocean sector of Southern Ocean $\left(62^{\circ} \mathrm{S}-69^{\circ} \mathrm{S}, 30^{\circ} \mathrm{E}-80^{\circ} \mathrm{E}\right)$. Gravid females were sorted and kept individually in an aquarium on board to enable collection of embryos. The embryos were kept in jars in a temperature controlled room $\left(0.5^{\circ} \mathrm{C}\right)$ until hatching and development through to nauplius stages. On arrival in Hobart, these larvae were transferred to the research facility in the Australian Antarctic Division Headquarters in Kingston $\left(0.5^{\circ} \mathrm{C}\right.$ temperature controlled laboratory). After larvae developed to CI, they were kept individually in $70 \mathrm{ml}$ jars, and fed on mixture of Instant algae (Reed Mariculture Inc., USA) Thalassiosira weisflogii, and live algae Phaeodactylum tricornutum (1$2 \mathrm{mg} \mathrm{C} / \mathrm{L}$ ). They were checked for moults, and debris was removed daily. Water was changed and food was added every $3-4$ days.

The starting points of the experiment were determined for each individual when they moulted into F IV or F V (6.5-8.0 $\mathrm{mm}$ in size). Larvae were kept in $200 \mathrm{~mL}$ plastic jars individually at $-0.5^{\circ} \mathrm{C}$ under either fed or starved conditions. The fed group was supplied continuously with Instant Algae T. weisflogii and live algae P. tricornutum (1-2mg C/L), and the starved group was kept in filtered seawater $(1 \mu \mathrm{m})$. After $0,5,10,15,20$ and 25 days, three larvae were sampled from both groups for TEM analysis.

Larvae sampled were placed in $2.5 \%$ glutaraldehyde in Sörensen's phosphate buffer $+5 \%$ sucrose at $\mathrm{pH} 7.2$ over night. After rinsing samples in Sörensen's buffer for more than $1 \mathrm{~h}$, they were post fixed in $1 \%$ osmium-tetroxide in Sörensen's buffer for $2 \mathrm{~h}$. Later the samples were dehydrated through an ethanol series and embedded in Spurr resin. Ultrathin sections were mounted on copper grids (400 mesh) and stained with uranyl acetate and lead citrate for 5 and $10 \mathrm{~min}$ respectively. TEM images were obtained with a Philips CM 100 transmission electron microscope.

\section{Results}

\section{Fed larvae}

In larval digestive glands, R-cells were found to be the most abundant cell type consisting of digestive epithelium. R-cells of fed larvae had numerous mitochondria scattered homogenously throughout the cells. Well ordered and packed microvilli were observed in the apical end, and smooth basal lamina covered the basal end of cells (Fig. 1a). Electron dense tips occurred on the cell surface between the microvilli and within the apical cytoplasm (Fig. 1b). Smooth endoplasmic reticulum (SER) was well developed in the apical region of R-cells closely associated with microvilli, which is an indication of the active accumulation of nutrients from the lumen (Fig. 1c). A few lipid droplets were observed in R-cells of a larva which fed for 15 days (Fig. 1 d).

\section{Starved larvae}

The ultrastructure of R-cells showed a quick response to starvation. Mitochondria were swollen and concentrated in the apical region. The cell volume was markedly reduced and the basal lamina was thickened with many irregular infoldings after starvation (Fig. 2a). SER was observed associated with thickened basal lamina in the basal region of R-cells (Fig. 2b). Numerous swollen mitochondria were observed in apical region of R-cells of starved larvae, and they were often surrounded by small vesicles (Fig. 2c). Mitochondria were swollen as early as 5 days of starvation and throughout the experiment, except for the samples from day-15 (Fig. 3). Few lipid droplets were found in the R-cells of a larva which was starved for 5 days. After 25 days of starvation no clear structural differences were observed on microvilli of R-cells compared to those from fed larvae. 

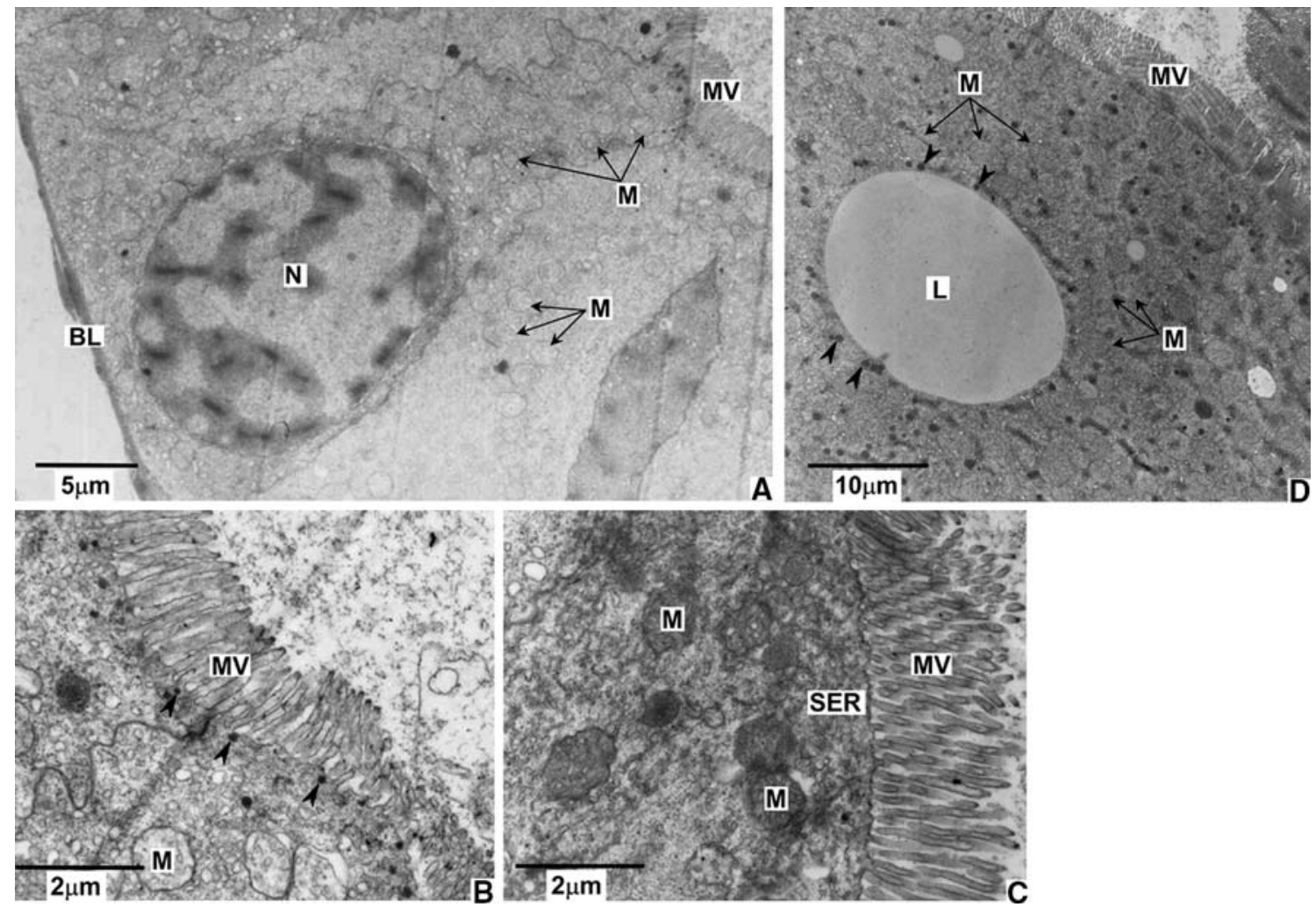

Fig. 1 R-cell of Euphausia superba larvae (fed). a Microvilli (MV) are well developed on apical surface of R-cells. Numerous mitochondria (M) occurred throughout R-cells. b Electron dense tips (arrowheads) occurred in apical region of R-cells. c Smooth endoplasmic

\section{Discussion}

The effects of starvation on the ultrastructure of R-cells in krill larvae were demonstrated using TEM in this study. After as early as 5 days of starvation an increase in the size of mitochondria was observed and the thickened basal lamina with irregular infoldings was observed after 10-15 days of starvation (Fig. 2a, b). These findings were consistent with those reported in decapod larvae Hyas araneus (Storch and Anger 1983). However, the magnitude of the overall increase in krill mitochondria size found in the present study was not as substantial as those found in decapods (Vogt et al. 1985).

Storch and Anger (1983) found that in decapod larvae, re-feeding after 8 and 12 days starvation did not result in a complete recovery of the affected R-cells, and concluded that the original ultrastructure of R-cells cannot be re-established after a certain period of food deprivation (PNR). Enlargement of mitochondria in R-cells in krill larvae suggest a diminished ability to take up food after 5 days of food deprivation. R-cells differentiate from E (embryonic)cells. E-cells are at the distal end of digestive tubules, and produce new cells when the tubules elongate at each moult to cover the break-down of R-cells at the proximal end of reticulum (SER) are developed in apical region of R-cells. d Lipid droplet $(\mathrm{L})$ is surrounded by mitochondria and electron dense inclusions (arrowheads). $N$ Nucleus, $B L$ basal lamina

tubules (Al-Mohanna and Nott 1989). The R-cells with swollen mitochondria and thickened basal lamina appear to lose their ability to take up nutrients. It is likely that the animal may need to wait until they have a sufficient number of $\mathrm{R}$-cells that can be built on to the distal end of digestive tubules to uptake the food again. Therefore, whether or not the animal can survive is dependent on the amount of reserve they have until enough new R-cells have been differentiated from the E-cells to fulfil the energy demand.

In the present study lipid droplets were rarely found in R-cells of krill larvae regardless of whether they were fed or starved. It is known that some decapod species cease or decrease feeding from pre-moult to post-moult stages, and feed actively at the inter-moult stages (Lipcius and Herrnkind 1982; Al-Mohanna and Nott 1989; Heals et al. 1996). This implies the necessity of building reserves in the Rcells for utilisation during the non-feeding moult stages. Indeed the maximum lipid reserves in R-cells were observed at the pre-moult stages of $\mathrm{D}_{0}$ and $\mathrm{D}_{1}$ in decapod (Al-Mohanna and Nott 1989). However, euphausiids are known to be less impaired by moulting compared to decapods, enabling a swarming pelagic life (Buchholz 1989, 1991). Schmidt et al. (2004) observed continuous feeding throughout the moult cycle of furcilia larvae and 
Fig. 2 R-cell of Euphausia superba larvae (starved). a Cell volume is markedly reduced with a high nucleus/cytoplasm ratio. Basal lamina (BL) is thickened and has irregular infoldings (starved 25 days). b Smooth endoplasmic reticulum (SER) was developed in basal region of $\mathrm{R}$-cell. Basal lamina is significantly thickened (starved 15 days). c Mitochondria (M) are swollen and concentrated in apical region. Many vesicles occurred apically (starved 20 days). $N$ Nucleus, $M V$ microvilli
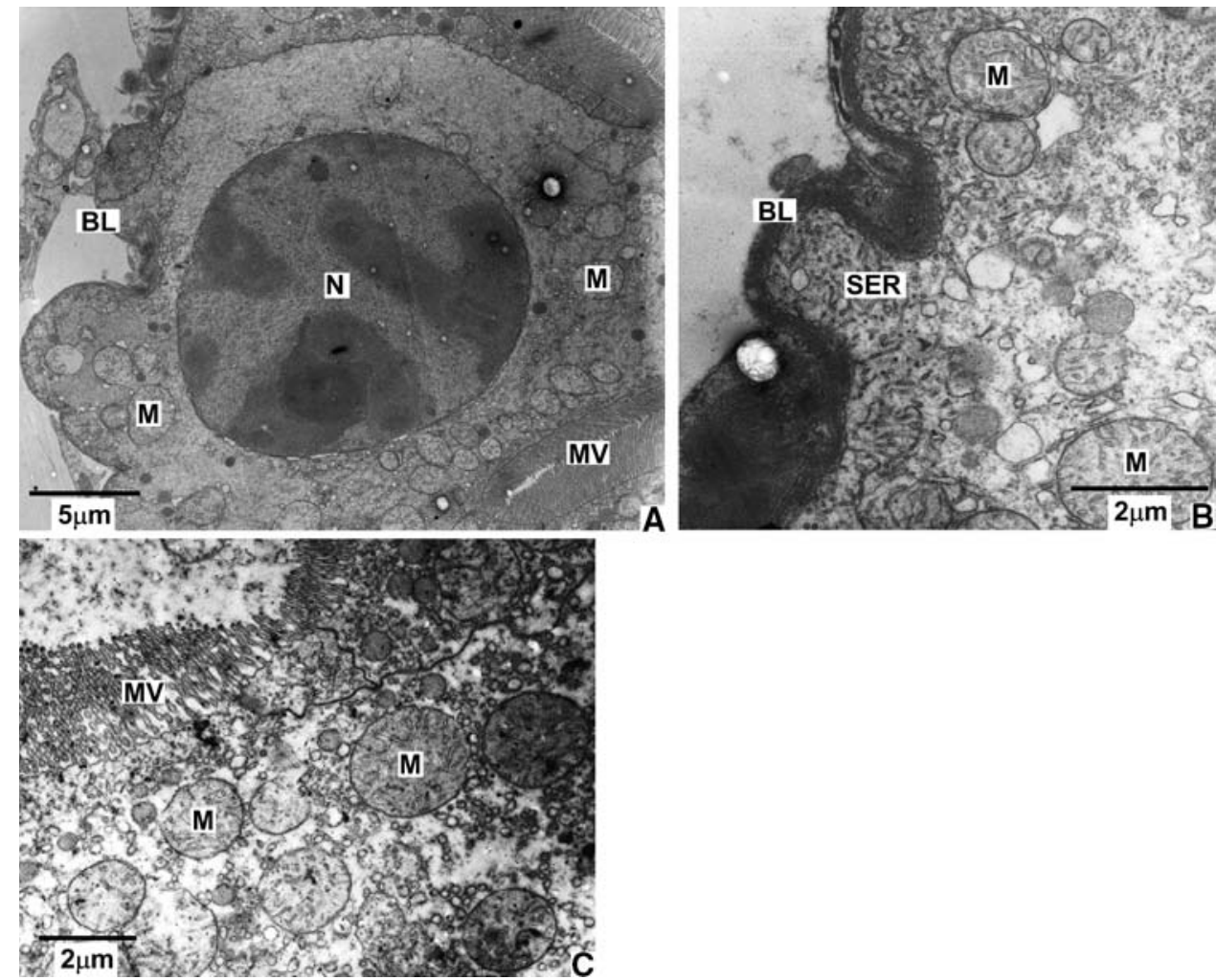

experimental period in which they were either fed or starved. These results also suggest that larvae used the energy from their diet for growing rather than for lipid storage, which is consistent with the observation of Meyer et al. (2002).

Digestive cells of krill larvae may however, retain an ability to take up food after a period of starvation, and/or generate new cells in the digestive gland. An observation was made in the present study where one of the FV larva developed into a juvenile after 20 days of starvation (Yoshida, unpublished). To examine the ability to recover after starvation, further longer term controlled experiments need to be conducted using larval krill subjected to starvation and re-feeding regimes.

In summary, the effects of starvation on the ultrastructure of the digestive gland of krill larvae were observed as early as 5 days, and these effects increased with duration of starvation. Lipid droplets were rarely found in the R-cells regardless of whether the larvae were fed or starved. These observations indicate that krill larvae are adapted to an environment where the food supply is continuous. Results from this study support the hypothesis that larval krill survival is dependant on the food supply associated with sea-ice during winter (Marschall 1988; Daly 1990; Ross and Quetin 1991).

Acknowledgments We thank the officers and crew of RV 'Aurora Australis' for their professional and friendly support during the marine research cruise BROKE-West, and Paul Cramp and Rob King for assistance with krill incubation. We are very grateful to Stephen Nicol for his critical reading of manuscript. We also thank Rob Massom, 
Margaret Lindsay and Andrew Constable for constructive comments on manuscript. This work is a contribution towards the output of the Antarctic Marine Ecosystems Program of the Antarctic Climate and Ecosystem, Co-operative Research Centre funded by the Australian Governments Co-operative Research Centres Programme. Two anonymous reviewers are gratefully acknowledged for their helpful comments on this manuscript.

\section{References}

Al-Mohanna SY, Nott JA (1989) Functional cytology of the hepatopancreas of Penaeus semisulcatus (Crustacea: Decapoda) during the moult cycle. Mar Biol 101:535-544

Buchholz F (1989) Moulting cycle and seasonal activities of chitinolytic enzymes in the integument and digestive tract of the Antarctic krill, Euphausia superba. Polar Biol 9:311-317

Buchholz F (1991) Moult cycle and growth of Antarctic krill Euphausia superba in the laboratory. Mar Ecol Prog Ser 69:217-229

Daly KL (1990) Overwintering development, growth and feeding of larval Euphausia superba in the Antarctic marine ice zone. Limonol Oceanogr 35(7):1564-1576

Hagen W (1988) On the significance of lipids in the Antarctic zooplankton. Rep Polar Res 49:1-129

Hagen W, Kattner G, Terbrüggen A, Van Vleet ES (2001) Lipid metabolism of the Antarctic krill Euphausia superba and its ecological implications. Mar Biol 139:95-104

Heals DS, Vance DJ, Loneragan NR (1996) Field observation of moult cycle, feeding behaviour, and diet of small juvenile tiger prawns Penaeus semisulcatus in the Embley River, Australia. Mar Ecol Prog Ser 145:43-51

Lipcius RN, Herrnkind WE (1982) Moult cycle alterations in behaviour, feeding and diel rhythms of a decapod crustacean, the Spiny lobster Panulirus argus. Mar Biol 68:241-252
Marschall H-P (1988) The overwintering strategy of Antarctic krill under the pack-ice of the Weddell Sea. Polar Biol 2:245-250

Meyer B, Oettle B (2005) Effects of short-term starvation on composition and metabolism of larval Antarctic krill Euphausia superba. Mar Ecol Prog Ser 292:263-270

Meyer B, Atkinson A, Stübing D, Oettle B, Hagen W, Bathmann UV (2002) Feeding and energy budgets of Antarctic krill Euphausia superba at the onset of winter I. F III larvae. Limnol Oceanogr 47:943-952

Quetin LB, Ross RM (2003) Episodic recruitment in Antarctic krill Euphausia superba in the Palmer LTER study region. Mar Ecol Prog Ser 259:185-200

Ross RM, Quetin LB (1989) Energetic cost to develop to the first feeding stage of Euphausia superba Dana and the effect of delays in food availability. J Exp Mar Biol Ecol 133:103-127

Ross RM, Quetin LB (1991) Ecological physiology of larval euphausiids, Euphausia superba (Euphausiaceae). Mem Queensl Mus 31:321-333

Schmidt K, Tarling GA, Plathner N, Atkinson A (2004) Moult cyclerelated feeding rates of larval krill Meganyctiphanes norvegica and Thysanoessa spp. Mar Ecol Prog Ser 281:131-143

Smith RC, Dierssen H, Vernet M (1996) Phytoplankton biomass and productivity in the western Antarctic Peninsula region. In: Ross RM, Hofmann EE, Quetin LB (eds) Foundations for ecological research west of the Antarctic Peninsula. American Geophysical Union, Washington DC, pp 333-356

Storch V, Anger K (1983) Influence of starvation and feeding on the hepatopancreas larval Hyas araneus (Decapoda, Majidae). Helgolander Meeresun 36:67-75

Vogt G, Storch V, Quinitio ET, Pascual FP (1985) Midgut gland as monitor organ for the nutritional value of diets in Penaesu monodon (Decapoda). Aquaculture 48:1-12 